\title{
Federalism and the Challenges of Nation Building in Nigeria
}

\author{
Chijioke Basil Onuoha* \\ Department of Political Science and Public Administration, University of Uyo, Akwa Ibom State, Nigeria \\ John E. Bassey \\ Department of Political Science and Public Administration, University of Uyo, Akwa Ibom State, Nigeria \\ Henry Ufomba \\ Department of Political Science and Public Administration, University of Uyo, Akwa Ibom State, Nigeria
}

\begin{abstract}
Nation-building is about building the tangible and intangible threads that hold a political entity together and gives it a sense of purpose. It was the belief of Nigerian nationalists that federalism will foster nation building in Nigeria, but fifty-eight years down the line as an independent nation, Nigeria is still grappling with challenges of nation building. Acknowledging this as a threat to the nation continued existence this paper discusses the implication of the continued practice of skewed federalism "Nigeria Model" and it effect on the country quest to become a strong and united nation. Adopting the descriptive method of enquiry as well as Integration paradigm as analytical guide, the paper argues that though federalism is the most suitable principle for ensuring nation building in a heterogeneous country like Nigeria, the "Nigeria Model" of federalism where so much fiscal resources and responsibilities is being concentrated in the center to the detriment of the states breeds confrontation between the central government and component units, thus hamper nation building. For empirical analysis, this study makes a survey of 1500 government officials and citizens out of which 1346 questionnaires were returned. The data obtained was analyzed using Pearson Correlation which showed a significant relationship between nation building and three key variables (federal structure, citizen perception of the political structure, and interaction of the tiers of government). The paper recommends, among other things, a review of the 1999 constitution to reduce the power and responsibilities of the federal government to common services like Foreign Affairs, Currency, Immigration and Defence and granting of more responsibilities to states as well as a reintroduction of the Derivation Principle which allow states generate it revenue from the resources available in it domain and give a percentage to the central government. This will bring out ingenuity inherent in the various states and lead to healthy competition in terms of development. This proposed new federal arrangement will not only give confidence to but enhance nation building in the country.
\end{abstract}

Keywords: Federalism ; Nation building ; Nigeria.

(c) (1) CC BY: Creative Commons Attribution License 4.0

\section{Introduction}

Nigeria is a country with an estimated 350 ethnic groups which have largely contiguous territories. These features make it a natural candidate for a federal system of government. Federalism is a political structure that allows states to unite under a central government to maintain a measure of independence and interdependence. This governance pattern which appears as a compromise formula allows for power sharing between national and state governments. It is generally regarded as the appropriate governmental principle for countries with huge ethnocultural diversities.

Successive government in Nigeria have tried with different degrees of sincerity, commitment and effort to operate federal institutions that can accommodate the country's ethnic, cultural, religious and linguistic diversities and nurture a sense of national unity. It was the belief of the Nigerian nationalist that a federal system of governance was most suitable for the country as this will generate stability which will eventually lead to a strong and united nation. For instance, while chief Awolowo contended that "the constitution of Nigeria must be federal...any other constitution will be unsuitable and will generate ever-recurring instability which may eventually lead to the complete disappearance of the Nigeria composite state." Sir Ahmadu Bello contended that federalism provided the "only guarantee that the country will grow evenly all over, we can spend the money we receive, the money we raise, in the direction best suited to us." (Odukoya and Ashiru, 2007).

Despite, the adoption of federalism as a governance strategy in Nigeria, the aspiration of nation building and national integration have not been achieve in the last fifty eight years of the existence. Undeniably, it could be observed that from independence until now the centrifugal forces remain pre-eminence. The complicatedness of attaining a united nation after independence has often aggravated worries and contention as to the viability of the Nigeria state.

The failure of the different tier of government in the country to discharge their responsibilities of good governance which is predicated on equitable political arrangement, transparent administrative practices and accountability in public affairs as well as failure to encourage genuine power sharing has brought about dodgy 
rivalries between the federal government and the other tier of government over revenue from oil and other natural resources tapped from the country.

Furthermore, this defective federal structure has also brought about agitation from various interest groups who are bend on capturing the state and the benefit associated with it, as well as ease the emergence of violent ethnic militia. As a result of the wonky nature of the Nigeria federal arrangement nation building, stability and socioeconomic development becomes a serious challenge. In view of the above, this paper sets to $\mathrm{x}$-ray the challenges pose by Nigeria's federalism on nation building.

\subsection{Statement of Problem}

The crux of the problem, which generated this descriptive analysis of the nation federalism, is the fact that the task of nation building has become very difficult in Nigeria and the fruit so patchy despite the operation of a federalist system in the country since independence. The attraction for federalism in Nigeria was induced by its perceived integrative tendency, which makes it capable of serving heterogeneous societies. It was adopted to quell the fear of mutual distrust and suspicion of domination among groups, to ensure economic prosperity and for the desire of unity in diversity.

However, a colossal look at the country today shows that it is tilling towards disintegration, there is mutual distrust and domination of some groups over the others as well as large scale poverty. The country federal practice has not been able to sufficiently provide the magic rod or formula that can directly resolves the problems and contradictions of the Nigerian state there by leading to national integration. This is because the core principle of federalism which posits that "no level of government is subordinate to the other" in a federal state is not adheres to in the country.

The Nigeria federal practice gives too much responsibilities and control to the central government. The exclusive legislative list which is superintended by the federal government contains sixty eight items while the concurrent list in which both the central and state government administer have only thirty items Federal Republic of Nigeria (1999). The "Kwashiorkor" nature of Nigerian federalism leaves too many responsibilities and resources at the federal level this does not allow for efficiency and this is done at the expense of the state. Nigeria is too far flung for a central authority to effectively perform some of the duties ascribe to the central government. The limitations to the competence of states in matters on the concurrent list by which state laws are constitutionally rendered null and void to the extent of their inconsistencies with federal law does not allow for nation building in Nigeria. Armed with these observations, this paper sets out to answer the following questions:

1. What impact does the federal structure of Nigeria today have on the level of nation building of nation building in the country?

2. What impact does the perception of the citizens of the political structure in the country have on the level of nation building?

3. What impact does the interaction between the tiers of government in Nigeria have on the level of nation building in the country?

\section{Framework of Analysis: Integration Theory}

The integration theory as propounded by Myron Weiner was adopted as a framework of analysis for this study. According to Weiner (1971), integration may refer to the process of having together groups characterized by its own language or other self-conscious cultural qualities. This is territorial integration which implies that the territory must be in existence under the control of one state and one government, like the Nigerian State and that the authority of the central government must be firmly established over all the country's territories. The ultimate goal of national integration as a process (irrespective of the preferred strategy) therefore, is the political unification of the constituent units into one whole nation. National integration is one among the five types of integration identified by Weiner. The others are: territorial, value, elite-mass and integrative behavior (Weiner, 1971).

According to Weiner, national integration refers specifically to the problem of creating a sense of territorial nationality which overshadows or eliminates-subordinate parochial loyalties. This integration involves amalgamation of disparate social, economic, religious, ethnic, and geographic elements into a single nation-state, a homogenous entity, the like of Plato's Polis, the city-state. This kind of integration implies both the capacity of government to control the territory under its jurisdiction as well as to stimulate a set of popular willingness by the people to place national interest above local or parochial concern towards the nation generally. Also, where national integration thrives, the individuals realized their rights and privileges identify fully with the state and owe allegiance to it, because they see themselves as standing in direct relation with it.

Federalism was seen as a system that would enhance national integration and nation building in a heterogeneous entity like Nigeria. Hence, it adoption and application in the county since independence, however, fifty eight years down the line, the country is still grapple with the issues of disunity and alienation among the various ethnic nationalities due to the skewed features of it federalism which poses a great challenge to nation building.

\subsection{Conceptual Explications}

\subsubsection{Federalism}

There are many literatures on the subject of federalism, however there are consensus among scholars that the core element of federalism is the existence of a system based on the sharing of power between at least two levels of government (federal and state) that allows each level to make final decisions on matters concurrently and 
exclusively. Two prominent schools of thought surface in the explanation of the meaning and nature of federalism. First is the orthodox school led by K.C. Wheare which sees federalism as a condition and the revisionist school led by Fredrich which sees it as process.

Wheare (1963) states rigid conditions for the concept of federalism. According to him "federalism means the method of dividing powers so that federal and regional governments are each, within a sphere, coordinate and independent". Wheare (1963) conceptualized federalism with the American union as the basis of his thesis. He sees federalism as the formal division of powers between levels of government. In his view "federal government is an association of states so organized that power are divided between a general government, which in certain matters independent of the governments of the associated states, and on the other hand, state governments, which in certain matters are in their turn, independent of the general government" Wheare (1963) further states that people will adopt the federal system if they desire a single coercive force in some aspects and independent of the units in other aspects. $\mathrm{He}$ added that "by the federal principle, I mean the method of dividing powers so that general and regional governments are each within a sphere, co-ordinate and independent".

This statement of the federal principle is qualified by Wheare's pointing out that it is a principle of organization and practice whose ultimate test is how the federal system operates. Wheare further listed conditions under which such a polity can exist and be sustained. These include among others, the formal and legal divisions of powers and responsibilities among levels of government as manifested in a written constitution, the establishment of an independent judicial system particularly the Supreme Court. A broad observation of Wheare's grounds indicates certain propositions, ensuring the gradual evolution of federalism from the consent of the people rather than dictatorial clique (Wheare, 1963).

He states thus: "dictatorship, with its one party government and its denial of free election, is incompatible with the working of the federal ethos. Federalism demands forms of government which have the characteristics usually associated with democracy or free government. There is a wide variety in the forms which such governments may take but the main grounding ingredients are free and fair election and party system with good atmosphere for responsible opposition (Aniekwe and Kushie, 2011; Jinadu, 2004). Although, Wheare has been criticized by other commentators for being legalistic, formal, rigid, euro-centric and idealistic, his formulation continued to serve as the springboard for subsequent analyses.

On his part, Friedrich (1966) attempt to avoid the pitfalls of Wheare by rather taking a wider view of federalism, and argued that federalism is a process rather than a design. He argued that federalism should be seen as a process by which unity and diversity are politically organized and this process includes, like all political phenomena, persons, institutions and ideas. He asserts "that federalism is a general principle of social organization and that the degree of federalism in a political system is a function of sociological and not legal criteria". He also sees federalism as dynamic and contended that the federal instrumentalities can be found in several forms of political systems, ranging from centralized to decentralized form. He declared that studies in contemporary times sort the dynamics of federalism not within its legal construct or constitutional document, but in the social forces that link or underline the political process.

(Fredrick, 2008) also believed that federalism is a process and not an institution or a design. He argues that any particular design or pattern of competencies or jurisdiction is merely a phase, a short run view of continually evolving political reality. To him, therefore, if so understood as the process of federalism, it will become apparent that federalism may be operating in both the direction of integration and differentiation. Consequently, federalism should be seen as a process by which unity and diversity are politically organized and these processes include political phenomena, persons, ideas and institutions put differently. This means we understood federalism as a general principle of social organization and that some degree of federalism resides in every political system. In comparison, however, many people do not acceptably define the characteristics of federalism because those existing federal systems do not all embody these criteria and where they do, there are identifiable variations from one federal system to another. For example, it is difficult to classify Switzerland and Canada as federal states but as quasi federal.

In the same vein Olayiwola (2016) observed that the essence of federalism lies not in the institutional or constitutional structure but in the society itself. He maintained that federal government is a device by which the federal qualities of the society are articulated and protected (Olayiwola, 2016). He further identifies the territories' demarcation of diversities as a distinguishing characteristic of federal government. In his words '

These diversities may be distributed to the members of a society in such a fashion that certain attitudes are found in particular territorial area, or they may be scattered widely throughout the whole of the society. If they are grouped territorially, then the result may be society that is federal. If they are not grouped territorially, then the society cannot be said to be federal.....But in the former case only can this take the form of federalism or federal government. In the latter case, it becomes functionalism, pluralism or some form of corporatism (Olayiwola, 2016).

Perhaps, what is more unique about Olayiwola's postulation is the introduction of the notion of "spectrum federalism" because it removes the rather common idea of an ideal federalism. As he asserts "federalism is not an absolute but relative term; there is no specific point at which a society ceases to be unified and becomes diversified. The differences are of degree rather than of kind. All countries fall somewhere in a spectrum, this runs from...A theoretically wholly integrated society at one extreme to a theoretically wholly diversified at the other".

In the words of Olu-Adeyemi (2017) federalism is an ambiguous term which has no clear or universally acceptable meaning apart from its philosophical terminology, including its differentiated approaches. The word 
federalism to him is used to make useful a useless situation defined by its diversified operation in the world and which has found expression in such terms as quasi federalism, cooperative federalism, organic federalism dual federalism or even decentralization. Federalism refers to the mixed or compound mode of government, combining a general government (the central or 'federal' government) with sub regional governments in a single political system. Its distinctive feature, exemplified in the founding example of modern federalism of the United States of America under the Constitution of 1789 , is a relationship of parity between the two levels of government established. It can thus be defined as a form of government in which there is a division of powers between two levels of government of equal status.

According to Jinadu (2004) "A federal state is nothing but a political contrivance intended to reconcile national unity with the maintenance of state rights". He cited a lot of scholars who have contributed to the literature of federalism. According to him, a popular American writer Hamilton described it as an association of states that form a new one". Federalism to Montesquieu is a convention by which several similar states agree to become members of a larger one". Finer on the other hand sees federal state "as one in which part of authority and power is vested in the local areas while another part is vested in a central institution deliberately constituted by an association of local area. Federalism is a political ideology that implies a division of governmental powers between the national government and the constituent units which may well be states or provinces and or regions (Jinadu, 2004).

However, the point must be made that the mere presence of a federal arrangement of governmental powers and political structures does not however, suggest that federalism has taken root. It must among other things, be able to guarantee and allow for the preservation of regional autonomy and the right to self-rule without foreclosing the possibilities of shared rule (Odukoya and Ashiru, 2007). This is achievable only at the point when federalism accommodates diverse groups and their interests. The moment the above condition is missing, as is the case with Nigeria where Federalism remains so only in name, the challenge of galvanizing the various interest in the polity becomes of great concern and the prospect for nation building becomes much exigent.

\subsubsection{Nation Building}

Nations are an important part of modern society and as an integral part of the modern societies; Nigeria is rightly concerned about nation-building. Nation-building is the product of conscious statecraft, not happenstance. Nation-building is always a work-in-progress; a dynamic process in constant need of nurturing and re-invention. Nation-building never stops and true nation-builder never rest because all nations are constantly facing up to new challenges (Harris, 2012).

According to Walker (2011) nation-building has many important aspects. Firstly, it is about building a political entity which corresponds to a given territory, based on some generally accepted rules, norms, and principles, and a common citizenship. Secondly, it is also about building institutions which symbolize the political entity institutions such as a bureaucracy, an economy, the judiciary, universities, a civil service, and civil society organizations. Above all else, however, nation-building is about building a common sense of purpose, a sense of shared destiny, a collective imagination of belonging. Nation-building is therefore about building the tangible and intangible threads that hold a political entity together and gives it a sense of purpose. Even in these days of globalization and rapid international flows of people and ideas, having a viable nation remains synonymous with achieving modernity. It is about building the institutions and values which sustain the collective community in these modern times.

(Deutsch, 1966) is of the opinion that the process of nation-building could be seen as an architectural design or a mechanical model that could be built based on authority, needs, and plan of the designer. To achieve unity, Hippler (2005) believes that at this stage, nation-building involves the citizens' loyalty towards their country of residence, and reduces their prioritizing towards their own ethnic group. There are researchers that refer to them as a community that is formed historically through the sharing of similar territories, economy and traditional elements that embody language, culture and name. Most countries involved in the process of nation-building are former colonies.

Originally, nation-building referred to the efforts of newly-independent nations, notably the nations of Africa but also in the Balkans, Harris (2012) to reshape territories that had been carved out by colonial powers or Empires without regard to ethnic, religious, or other boundaries (Deutsch and Foltz, 2010). These reformed states would then become viable and coherent national entities (Walker, 2011). Nation-building includes the creation of national paraphernalia such as flags, anthems, national days, national stadiums, national airlines, national languages, and national myths (Hippler, 2005). At a deeper level, national identity needed to be deliberately constructed by molding different ethnic groups into a nation, especially since in many newly established states colonial practices of divide and rule had resulted in ethnically heterogeneous populations (Harris, 2012).

The process of nation-building is an effort to develop the spirit of patriotism and solidarity to create a country whose people share a common identity. The major aim is to foster national unity by developing a new nation and an integrated race (Hippler, 2005).

According to (Walker, 2011) Nation-building refers to the process of constructing or structuring a national identity using the power of the state. This process aims at the unification of the people within the state so that it remains politically stable and viable in the long run. Nation-building can involve the use of propaganda or major infrastructure development to foster social harmony and economic growth. It is also the development of behaviors, values, language, institutions, and physical structures that elucidate history and culture, concretize and protect the present, and ensure the future identity and independence of a nation. Nation-building also includes efforts to promote institutions which will provide for economic wellbeing and social equity. 


\section{Empirical Analysis}

In this section data obtained from the field will be used to measure federalism and the challenges of nation building in the country. Our a-priori expectations are:

1. There is no significant relationship between the federal structure of Nigeria and the level of nation building.

2. There is no significant relationship between citizen perception of the political structure of Nigeria and the level of nation building.

3. There is no significant relationship between the interaction of the tiers of government and nation building.

To obtain data for the empirical analysis 1500 questionnaires were distributed to key government officials and citizens in Abia and Akwa Ibom States. Out of the 1500 questionnaires 1346 was returned and considered valid for this study. The responses were captured using a 5 likert scale research instrument with the options expressed as; SA (Strongly Agreed), A (Agreed), Undecided (UD), D (Disagreed) and SD (Strongly Disagreed). The obtained data was analyzed below using Pearson Correlation.

Table-1. Questionnaire Responses to item 1: Do you agree that the federal structure of Nigeria today has a significant effect on the level of nation building of nation building in the country?

\begin{tabular}{|c|c|c|c|c|c|c|}
\hline & & $\begin{array}{l}\text { Strongly } \\
\text { Agreed }\end{array}$ & Agreed & Undecided & Disagreed & \begin{tabular}{|l|} 
Strongly \\
Disagreed
\end{tabular} \\
\hline \multirow{3}{*}{ Strongly Agreed } & Pearson Correlation & 1 & $.123^{* 4}$ & $.059^{*}$ & $-.431^{4 *}$ & $-.385^{4 *}$ \\
\hline & Sig. (1-tailed) & & .000 & .015 & .000 & .000 \\
\hline & $\mathrm{N}$ & 1346 & 1346 & 1346 & 1346 & 1346 \\
\hline \multirow{3}{*}{ Agreed } & Pearson Correlation & $.123^{4 *}$ & 1 & $-.090^{44}$ & $-.053^{*}$ & $-.047^{*}$ \\
\hline & Sig. (1-tailed) & .000 & & .000 & .026 & .041 \\
\hline & $\mathrm{N}$ & 1346 & 1346 & 1346 & 1346 & 1346 \\
\hline \multirow{3}{*}{ Undecided } & Pearson Correlation & $.059^{*}$ & $-.090^{* *}$ & 1 & -.026 & -.023 \\
\hline & Sig. (1-tailed) & .015 & .000 & & .174 & .201 \\
\hline & $\mathrm{N}$ & 1346 & 1346 & 1346 & 1346 & 1346 \\
\hline \multirow{3}{*}{ Disagreed } & Pearson Correlation & $-.431^{4 *}$ & $-.053^{*}$ & -.026 & 1 & $.893^{4 *}$ \\
\hline & Sig. (1-tailed) & .000 & .026 & .174 & & .000 \\
\hline & $\mathrm{N}$ & 1346 & 1346 & 1346 & 1346 & 1346 \\
\hline \multirow{3}{*}{$\begin{array}{l}\text { Strongly } \\
\text { Disagreed }\end{array}$} & Pearson Correlation & $-.385^{4 *}$ & $-.047^{*}$ & -.023 & $.893^{* *}$ & 1 \\
\hline & Sig. (1-tailed) & .000 & .041 & .201 & .000 & \\
\hline & $\mathrm{N}$ & 1346 & 1346 & 1346 & 1346 & 1346 \\
\hline
\end{tabular}

**. Correlation is significant at the 0.01 level (1-tailed). $\mathrm{P}>0.05$

Table-2. Questionnaire Responses to item 2: Do you agree that the perception of the citizens of the political structure in the country has a significant effect on the level of nation building?

\begin{tabular}{|c|c|c|c|c|c|c|}
\hline & & \begin{tabular}{|l|} 
Strongly \\
Agreed
\end{tabular} & Agreed & Undecided & Disagreed & $\begin{array}{l}\text { Strongly } \\
\text { Disagreed }\end{array}$ \\
\hline \multirow{3}{*}{ Strongly Agreed } & Pearson Correlation & 1 & $.137^{* 4}$ & $-.145^{* 4}$ & $-.272^{* 4}$ & $-.227^{* *}$ \\
\hline & \begin{tabular}{|l|} 
Sig. (1-tailed) \\
\end{tabular} & & .000 & .000 & .000 & .000 \\
\hline & $\mathrm{N}$ & 1346 & 1346 & 1346 & 1346 & 1346 \\
\hline \multirow{3}{*}{ Agreed } & Pearson Correlation & $.137^{* 4}$ & 1 & $-.118^{* *}$ & -.037 & -.031 \\
\hline & Sig. (1-tailed) & .000 & & .000 & .086 & .127 \\
\hline & $\mathrm{N}$ & 1346 & 1346 & 1346 & 1346 & 1346 \\
\hline \multirow{3}{*}{ Undecided } & Pearson Correlation & $-.145^{* *}$ & $-.118^{* *}$ & 1 & -.024 & -.020 \\
\hline & Sig. (1-tailed) & .000 & .000 & & .192 & .234 \\
\hline & $\mathrm{N}$ & 1346 & 1346 & 1346 & 1346 & 1346 \\
\hline \multirow{3}{*}{ Disagreed } & Pearson Correlation & $-.272^{* *}$ & -.037 & -.024 & 1 & -.006 \\
\hline & Sig. (1-tailed) & .000 & .086 & .192 & & .409 \\
\hline & $\mathrm{N}$ & 1346 & 1346 & 1346 & 1346 & 1346 \\
\hline \multirow{3}{*}{$\begin{array}{l}\text { Strongly } \\
\text { Disagreed }\end{array}$} & Pearson Correlation & $-.227^{* 4}$ & -.031 & -.020 & -.006 & 1 \\
\hline & Sig. (1-tailed) & .000 & .127 & .234 & .409 & \\
\hline & $\mathrm{N}$ & 1346 & 1346 & 1346 & 1346 & 1346 \\
\hline
\end{tabular}

**. Correlation is significant at the 0.01 level (1-tailed). 
Table-3. Questionnaire Responses to item 3: Do you agree that the level of interaction between the tiers of government in Nigeria has a significant effect on the level of nation building in the country?

\begin{tabular}{|c|c|c|c|c|c|c|}
\hline & & $\begin{array}{l}\text { Strongly } \\
\text { Agreed }\end{array}$ & Agreed & Undecided & Disagreed & $\begin{array}{l}\text { Strongly } \\
\text { Disagreed }\end{array}$ \\
\hline \multirow{3}{*}{ Strongly Agreed } & Pearson Correlation & 1 & $.089^{46}$ & $-.060^{\circ}$ & $-.935^{4 *}$ & $-.623^{4 *}$ \\
\hline & Sig. (1-tailed) & & .001 & .014 & .000 & .000 \\
\hline & $\mathrm{N}$ & 1346 & 1346 & 1346 & 1346 & 1346 \\
\hline \multirow{3}{*}{ Agreed } & Pearson Correlation & $.089^{* 4}$ & 1 & $-.062^{*}$ & $-.086^{4 *}$ & $-.055^{*}$ \\
\hline & Sig. (1-tailed) & .001 & & .012 & .001 & .021 \\
\hline & $\mathrm{N}$ & 1346 & 1346 & 1346 & 1346 & 1346 \\
\hline \multirow{3}{*}{ Undecided } & Pearson Correlation & $-.060^{\circ}$ & $-.062^{*}$ & 1 & $-.061^{*}$ & -.039 \\
\hline & Sig. (1-tailed) & .014 & .012 & & .013 & .078 \\
\hline & $\mathrm{N}$ & 1346 & 1346 & 1346 & 1346 & 1346 \\
\hline \multirow{3}{*}{ Disagreed } & Pearson Correlation & $-.935^{* 4}$ & $-.086^{6 *}$ & $-.061^{*}$ & 1 & $.639^{4 *}$ \\
\hline & Sig. (1-tailed) & .000 & .001 & .013 & & .000 \\
\hline & $\mathrm{N}$ & 1346 & 1346 & 1346 & 1346 & 1346 \\
\hline \multirow{3}{*}{ Strongly Disagreed } & Pearson Correlation & $-.623^{4}$ & $-.055^{*}$ & -.039 & $.639^{4 *}$ & 1 \\
\hline & Sig. (1-tailed) & .000 & .021 & .078 & .000 & \\
\hline & $\mathrm{N}$ & 1346 & 1346 & 1346 & 1346 & 1346 \\
\hline
\end{tabular}

**. Correlation is significant at the 0.01 level (1-tailed).

*. Correlation is significant at the 0.05 level (1-tailed).

The data analyzed in tables 1,2 and 3 shows that there are significant relationships between the key variables. Based on that we reject the three null hypotheses and accept the alternative hypotheses which are:

Alternative Hypothesis I: There is significant relationship between the federal structure of Nigeria and the level of nation building.

Alternative Hypothesis II: There is significant relationship between citizen perception of the political structure of Nigeria and the level of nation building.

Alternative Hypothesis III: There is significant relationship between the interaction of the tiers of government and nation building.

\section{Conclusion and Policy Prescription}

One of the major challenges facing Nigeria federal arrangement is how it can lead to nation building, this is because the issue of diversities - ethnic and religious have continually stifle national loyalty thus delegitimizing the central authority. Federalism as an appropriate governmental system to cope with the problem of maintaining unity in a diversified society and as an overriding model for harmonious living is facing great challenges in Nigeria particularly, how to galvanize the various ethic interest into becoming one strong and viable nation.

The preceding discussion shows that Nigeria federalism since 1960 has not yielded the expected result of spurring unity among the diverse ethnic groups in the country hence, nation building. This is attributed to the "Kwashiorkor" nature of the federal arrangement where there exists so much concentration of fiscal and political power at the center, leaving the state with little resources to meet it ever growing responsibilities. Consequent upon the above, the present federal arrangement cannot lead to nation building.

Therefore, the problems of nation - building in Nigeria would no longer be a serious challenge when the system is rearranged to allow states generate it revenue from the resources available in it domain and give a percentage as tax to the central government (Derivation Principle). This will bring out the ingenuity inherent in these states and lead to healthy competition in terms of development because each state would explore it area of comparative advantage. Added to this, is that the 1999 Constitution should be review to grant more responsibilities to the States; such as provision of water and management of water resources, policing, maintenance of roads and provision of tertiary education etc, and reduce the responsibilities of the federal government to common services like Foreign Affairs, Currency, Immigration and Defence. The great potentials of the country would be best realized within the framework of this proposed new federal arrangement.

\section{Conclusion and Policy Prescription}

One of the major challenges facing Nigeria federal arrangement is how it can lead to nation building, this is because the issue of diversities - ethnic and religious have continually stifle national loyalty thus delegitimizing the central authority. Federalism as an appropriate governmental system to cope with the problem of maintaining unity in a diversified society and as an overriding model for harmonious living is facing great challenges in Nigeria particularly, how to galvanize the various ethic interest into becoming one strong and viable nation.

The preceding discussion shows that Nigeria federalism since 1960 has not yielded the expected result of spurring unity among the diverse ethnic groups in the country hence, nation building. This is attributed to the "Kwashiorkor" nature of the federal arrangement where there exists so much concentration of fiscal and political power at the center, leaving the state with little resources to meet it ever growing responsibilities. Consequent upon the above, the present federal arrangement cannot lead to nation building.

Therefore, the problems of nation - building in Nigeria would no longer be a serious challenge when the system is rearranged to allow states generate it revenue from the resources available in it domain and give a percentage as tax 
to the central government (Derivation Principle). This will bring out the ingenuity inherent in these states and lead to healthy competition in terms of development because each state would explore it area of comparative advantage. Added to this, is that the 1999 Constitution should be review to grant more responsibilities to the States; such as provision of water and management of water resources, policing, maintenance of roads and provision of tertiary education etc, and reduce the responsibilities of the federal government to common services like Foreign Affairs, Currency, Immigration and Defence. The great potentials of the country would be best realized within the framework of this proposed new federal arrangement.

\section{References}

Aniekwe, C. and Kushie, J. (2011). Electoral violence situational analysis, Identifying hot-spots in the 2011 general elections in nigeria, National association for peaceful elections in nigeria(napen). Available: http://www.ifes.org/Content/Projects/AppliedResearchCeter/Cross- CuttinWElection-Violence-Educationand Resolution.aspx

Deutsch, K. (1966). Integrational political communities, An anthology. In, Deusch, $k$ et al political community and north atlantic area. oubleday: New York. Garden City. 355

Deutsch, K. and Foltz, W. (2010). Nation building in comparative contexts. AldineTransaction: New Brunswick N. J.

Federal Republic of Nigeria (1999). Constitution. Federal Government Press: Lagos.

Fredrick, C. (2008). Federalism is a process, Trends of federalism, A theory of federal political arrangement. Public education paper no.7 centre for the study of federalism in Canada.

Friedrich, C. J. (1966). Federalism and Opposition, Government and Opposition. J, New York.

Harris, M. (2012). The politics of nation-building: Making co-nationals, refugees, and minorities. Cambridge University Press: New York.

Hippler, J. (2005). Nation-building, A key concept for peaceful conflict transformation. London, Pluto.

Jinadu, L. (2004). Forword in, Gana, aron and egwu, sam (eds.), federalism in africa, Framing the national question. 1 vols.: Africa World Press Incorporation New Jersey.

Odukoya, A. and Ashiru, D. (2007). Federalism and the national question in nigeria. In: Anifowose, r. \& babawale, t. (eds). Nigeria beyond 2007 issues, challenges \& prospects. Department of Political Science, University of Lagos, Akoka: Lagos.

Olayiwola, V. O. (2016). Ethnic diversity in Nigeria, A purview of mechanism for national integration. Afro Asian Journal of Social Sciences, (7): 3.

Olu-Adeyemi, L. (2017). Federalism in Nigeria - problems, prospects and the imperative of restructuring. International Journal of advances in Social Science and Humanities, (5): 8.

Walker, C. (2011). Nation-building or nation-destroying. World Politics, 24(03): 319-41.

Weiner, M. (1971). Political integration and political development. In, Jason l. Finkle and richard w. Gable (eds.) political development and social change. John Wiley and Sons. Inc.: New York.

Wheare, K. C. (1963). Federal government. 4th edn: O.U.P.: New York. 